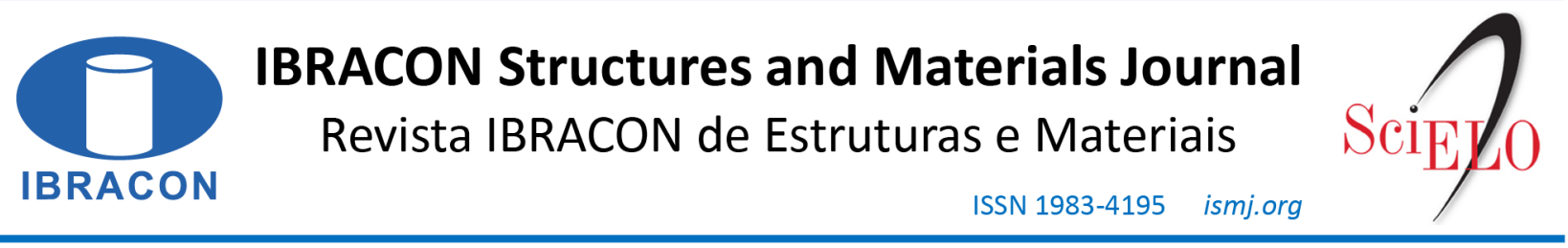

ORIGINAL ARTICLE

\title{
Size effect on the methodology with cylinder specimens for FRP-to-concrete debonding analysis
}

\section{Efeito de escala na metodologia para análise do descolamento entre concreto e PRF com corpos de prova cilíndricos}

\author{
Luana Ferreira Borges ${ }^{\mathrm{a}}$ (D) \\ Antonio Carlos dos Santos ${ }^{\mathrm{b}}$
}

${ }^{a}$ Universidade de Brasília - UnB, Departamento de Engenharia Civil e Ambiental, Programa de Pós-graduação em Estruturas e Construção Civil, Brasília, DF, Brasil

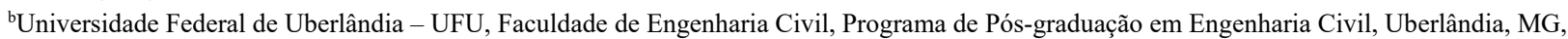
Brasil

Received 17 December 2019

Accepted 05 August 2020

\begin{abstract}
This is a study about the size effect on the methodology with concrete cylinder specimens for analysis of the debonding phenomenon at the interface between concrete and carbon fiber reinforced polymer (FRP). The influence of the concrete specimen size variation is analyzed by maintaining the same geometry in adhered FRP. Direct tensile experiments were performed with three dimensions of cylindrical concrete specimens (diameter $\times$ height) for analysis of size effect: $50 \mathrm{~mm} \times 100 \mathrm{~mm}, 100 \mathrm{~mm} \times 200 \mathrm{~mm}$, and $150 \mathrm{~mm}$ $\times 300 \mathrm{~mm}$. Ten different geometries of the composite material were tested. Two failure modes were observed in the experiments: debonding between the two materials and tensile failure in concrete specimens. In experiments with interface failure, the size of concrete specimens has no significant influence on maximum force, shear stress to peak, and stiffness in debonding between concrete and FRP. However, the use of smaller specimens for analysis of interface collapse is limited because the concrete reaches its normal stress capacity with a lower tensile force, and therefore, the failure often occurs in the concrete.
\end{abstract}

Keywords: size effect, debonding, FRP, direct tensile experiments.

\begin{abstract}
Resumo: Este trabalho apresenta um estudo sobre o efeito de escala na metodologia para análise do fenômeno do colapso de interface entre concreto e polímero reforçado com fibra (PRF) de carbono por meio de corpos de prova cilíndricos. Buscou-se analisar a influência da variação da dimensão do corpo de prova ao manter a mesma geometria de PRF aderida. Para a análise do efeito de escala, foram realizados experimentos de tração direta com três dimensões de corpos de prova cilíndricos (diâmetro $\times$ altura): $50 \mathrm{~mm} \times 100 \mathrm{~mm}, 100 \mathrm{~mm} \times$ $200 \mathrm{~mm}$, e $150 \mathrm{~mm} \times 300 \mathrm{~mm}$. Dez geometrias diferentes do material compósito foram testadas. Dois modos de falha foram observados nos experimentos: deslizamento entre os dois materiais e falha por tração no concreto. Nos experimentos com falha na interface, não se notou uma influência da dimensão do corpo de prova na força máxima, tensão de cisalhamento até o pico, e rigidez no descolamento entre concreto e PRF. No entanto, o uso de corpos de prova menores é limitado, pois muitas vezes é atingida a tensão normal limite que o concreto resiste, causando sua ruptura.
\end{abstract}

Palavras-chave: efeito de escala, descolamento, PRF, ensaios de tração direta.

How to cite: L. F. Borges and A. C. Santos, "Size effect on the methodology with cylinder specimens for FRP-to-concrete debonding analysis," Rev. IBRACON Estrut. Mater., vol. 14, no. 3, e14304, 2021, https://doi.org/10.1590/S1983-41952021000300004

\section{INTRODUCTION}

Fiber reinforced polymer (FRP) is one of the most modern materials for strengthening reinforced concrete structures. FRP application can be made in two ways: it is externally bonded reinforcement (EBR) on structural elements or, it is 
near surface mounted (NSM) within grooves on the concrete cover. A great progress occurred in FRP research and studies for structural strengthening of reinforced concrete structures [1], [2] in the last decades. As a result, various standards and design guidelines were published [1]-[3]. FRP is also used for strengthening of metallic structures [4]-[7], masonry [4], [6], [8], [9], and wood structures [6], [10], [11].

Some advantages, compared to the use of other strengthening materials, are that FRP are noncorrosive, they are materials with high strength-to-weight [12], [13], and high stiffness-to-weight [1], [2], [14]-[16] ratios. However, there are some questions about failure modes, in particular the collapse at the interface, which occurs by means of FRP and concrete debonding in regions of high stress concentrations. One of the main failure mechanisms in FRP-strengthening concrete structures is the loss of adhesion between substrates and strengthening. This failure mode was verified in some experiments (e.g. [17]-[20]). Many studies about debonding were conducted, but initiation and the failure mechanism, relationship with local phenomena and influence of materials are not fully understood [21].

Basically, the main tests for analyzing debonding between concrete and FRP include shear experiments (single or double) and beam tests [22]. The single shear test is the most common methodology [22]. In this test, one FRP sheet is adhered to a prismatic concrete sample, and force is applied to the FRP, which is pulled until debonding occurs. In the double shear test, tensile force is applied simultaneously on two FRP sheets [23]. This methodology is preferred over the previous due to symmetry and for better control of induced normal stresses [24]. Bending experiments on beams include three-point bending tests and four-point bending tests. These bending experiments are performed on a beam strengthened with FRP on its bottom face. Bending tests better reproduce the actual interfacial stress state, but such tests are cumbersome to set up [24]. A review of the experimental tests between FRP and concrete can be found in Mukhtar and Faysal [23], which presents the pros and cons of each of the test methods.

Santos et al. [25] proposed a direct tensile test on concrete cylinder specimens $(150 \mathrm{~mm} \times 300 \mathrm{~mm})$ for analysis of the bond strength of FRP-to-concrete joints (see Section: Methodology). They tested and corroborated this methodology. The authors demonstrated the reproducibility of the test. The main advantages of this test are the inexistence of large eccentricities, good reproducibility, the use of cylindrical specimens (a very common geometry in civil engineering), and one test allows obtaining three simultaneous interface tests [25]. Its main disadvantage is that the concrete specimens have a circular surface, while structural elements in which the debonding occurs are usually non-circular. However, the shear stress distribution along the length and the width of the FRP sheet has not been much influenced by the sheet curvature [25]. The objective of the present study was to evaluate this methodology with concrete cylinder specimens of different dimensions to analyze the size effect.

One of the main problems associated with the bond analysis is the significant difference between the largest dimension of the set (the length of a beam) and the smallest dimension (the thickness of the FRP strengthening) [26]. The debonding mechanism tend to follow the smallest geometrical dimension (the thickness of FRP), and the stress concentration associated with the debonding are distributed along few millimeters [26]. In this paper, the debonding mechanism is analyzed with direct tensile tests using $150 \mathrm{~mm} \times 300 \mathrm{~mm}$ cylinder specimens and with smaller concrete cylinders than proposed by Santos et al. [25] methodology. The effect of the use of smaller concrete specimens is analyzed on the maximum debonding force and the stiffness.

The size effect on mechanical properties of concrete was a topic of interest to several researchers. The size effect is the variation in the strength with size changes in geometrically similar structures [27]. The influence of specimen size was noticed in tensile strength, compressive strength [28]-[32] and other mechanical properties. Del Viso et al. [31] observed the size effect on compressive strength is more noticed in concrete cubic specimens, in comparison with concrete cylinder specimens. Not only the average strength, but also the variability of results decreases as specimens increases [29]. However, increasing size does not result in a reduced strength from a size value. In other words, the strength versus characteristic dimensions of the cross-section diagram presents asymptotic trends [33]. In addition, there is a transition from ductile behavior to brittle behavior with the increase in dimensions of concrete specimens [27], [34]. The influence of element dimensions on characteristics is a property of so-called quasi-brittle materials [35], [36], such as concrete. Quasi-brittle materials have a relatively large fracture process zone, compared to cross section of structure [34], [37]. The size effect is most acute and most complex in these materials [37]. Some studies analyze the size effect on the edge debonding between concrete and FRP [38], the interfacial shear stress concentration at the carbon FRP cut-off regions and the failure mode of FRP-strengthened beams as a function of beam size and FRP thickness [39], and a comparison between analysis of full-scale beams and small "laboratory scale" beams in a study focused on the intermediate crack (IC) debonding [26]. 


\subsection{Chen and Teng's model (2001)}

Various analytical models are available for predicting the force that causes debonding between concrete and FRP. In this study, the experimental results (direct tensile tests) are compared to values predicted using the Chen and Teng's [40] bond strength model. This model is simple, rational and accurate, and it is based on fracture mechanics and experimental observations [40]. Lu et al. [41] compared prediction of 12 models with 253 test results. They concluded that the Chen and Teng's model is accurate, with a low coefficient of variation and a high correlation coefficient [41].

An important aspect of the FRP-to-concrete bond behavior is that there exists a bond length from which its increase will not increase the ultimate load [14], [41]-[45]. The effective length (Le) is a parameter in various analytical models. This value is a characteristic of the adhesively bonded joints [43], and its definition is an important part of all FRP strengthening calculations [44]. Chen and Teng [40] propose Equation 1 to compute the effective bond length.

$$
L e=\sqrt{\frac{E_{p} t_{p}}{\sqrt{f_{c}^{\prime}}}}
$$

where $L e=$ effective bond length $(\mathrm{mm}) ; E_{p}=$ Young's modulus of the bonded FRP plate (MPa); $t_{p}=$ thickness of the bonded FRP plate $(\mathrm{mm})$; and $f_{c}$ ' $=$ cylinder concrete compressive strength (MPa).

In the Chen and Teng's [40] model, the prediction of maximum transferable load is made by Equation 2, in which the width ratio coefficient $\left(\beta_{p}\right)$ and the length ratio coefficient $\left(\beta_{L}\right)$ are defined by Equations 3 and 4 , respectively.

$P u=0.427 \beta_{p} \beta_{L} \sqrt{f_{c}^{\prime}} b_{p} L e$

$\beta_{p}=\sqrt{\frac{2-\left(b_{p} / b_{c}\right)}{1+\left(b_{p} / b_{c}\right)}}$

$\beta_{L}=\left\{\begin{array}{c}1 \text { if } \quad L \geq L e \\ \operatorname{sen}\left(\frac{\pi L}{2 L e}\right) \quad \text { if } \quad L<L e\end{array}\right.$

where $P u=$ maximum transferable load $(\mathrm{kN}) ; \beta_{p}=$ width ratio coefficient (dimensionless); $\beta_{L}=$ length ratio coefficient (dimensionless); $f_{c}^{\prime}=$ cylinder concrete compressive strength (MPa); $b_{c}=$ width of concrete member $(\mathrm{mm}) ; b_{p}=$ width of bonded FRP plate (mm); $L e=$ effective bond length (mm); and $L=$ bond length (mm).

\section{MATERIALS AND METHODS}

\subsection{Material properties}

The fiber reinforced polymer consists of fibers (the structural component of FRP) with trade name of MBrace 120 in the sheet system and epoxy resin (the polymer component of FRP) with trade name of Viapol Carbon Saturante. The carbon fiber with unidirectional orientation of fibers has $0.117 \mathrm{~mm}$ thickness, $3900 \mathrm{MPa}$ ultimate tensile strength, $240 \mathrm{GPa}$ modulus of elasticity, and $1.55 \%$ ultimate tensile elongation. The epoxy resin has $29 \mathrm{MPa}$ strength, $68 \mathrm{MPa}$ compressive strength and $1470 \mathrm{MPa}$ compression modulus. These properties are in the suppliers' catalogs.

The concrete is composed of cement containing pozzolanas (CPIV-32 cement), coarse basaltic aggregate (12.5 mm characteristic dimension), fine aggregate $(1.18 \mathrm{~mm}$ characteristic dimension), water, and a superplasticizer. The proportions of cement, sand, coarse aggregate and water to cement ratio is 1.00: 1.50: 1.99: 0.49 by weight. The superplasticizer with sulphonated naphthalene composition was added in a proportion of $1.5 \%$ cement weight. The mechanical properties of concrete were evaluated at 90 days on cylinder specimens (diameter $100 \mathrm{~mm}$, height $200 \mathrm{~mm}$ ). The mechanical properties of concrete are listed in Table 1. 
Table 1. Concrete material properties at 90 days.

\begin{tabular}{cccc}
\hline Mechanical property & Number of experiments & Average value & Sample standard deviation \\
\hline Compressive strength & 20 & $38.9 \mathrm{MPa}$ & $4.7 \mathrm{MPa}$ \\
\hline Modulus of elasticity & 30 & $36.5 \mathrm{GPa}$ & $3.6 \mathrm{GPa}$ \\
\hline Brazilian splitting test & 20 & $3.41 \mathrm{MPa}$ & $0.7 \mathrm{MPa}$ \\
\hline
\end{tabular}

\subsection{Methodology}

The direct tensile method proposed by Santos et al. [25] was used herein to analyze the bond capacity at the interface between FRP and concrete. In this methodology, two cylindrical concrete specimens are placed end-to-end and three FRP sheets are symmetrically adhered to the specimens (with an angle of 120 degrees between an FRP sheet and another FRP sheet). Each FRP sheet had three regions: upper adhesion region, unbonded region, and lower adhesion region. The length of the lower region is 1.5 times the length of the upper region to induce failure in the upper region. Figure 1 illustrates a scheme of specimen and FRP regions.

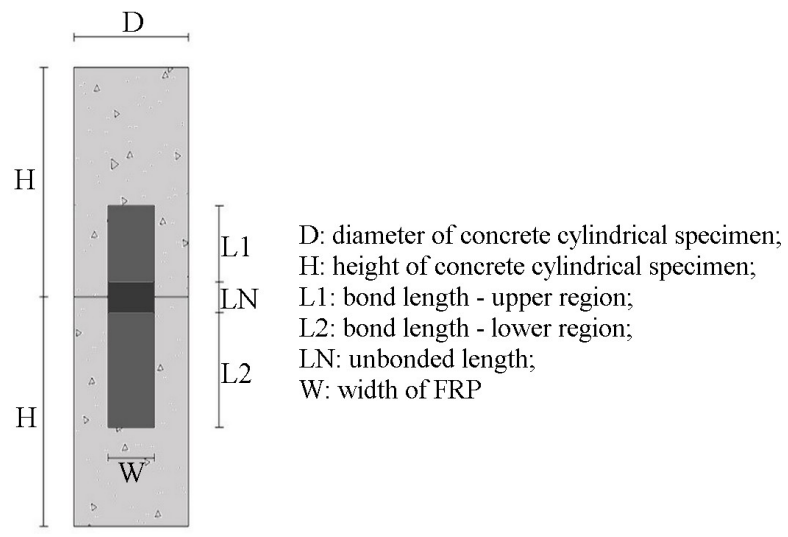

Figure 1. Specimen and FRP regions

Single shear test is one of the most performed experiments for analysis of debonding between concrete and FRP. The unbonded zone was adopted in some single shear tests with prismatic concrete specimens, but this region has not been tested in some experiments [41]. In shear experiments, a piece of concrete may be removed from the prism near the loaded end when the unbonded region does not exist or it is small [41]. However, this variation has no significant effect on the overall behavior provided the bond length is not too short [41].

In the static direct tensile test, the lower cylindrical specimen was fixed at its base, and a displacement of 0.12 micrometer per second was applied on the upper cylindrical specimen. Preparation of experiments is shown in the "Preparation of experiment" section. The application of tensile force induces the appearance of shear stresses at the interface between FRP and concrete. Data were acquired at a frequency of $10 \mathrm{~Hz}$. A scheme of the experiment is shown in Figure 2.

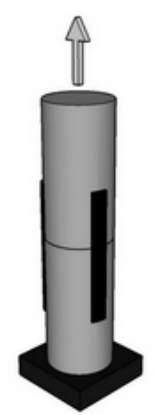

Figure 2. Aspect of direct tensile test. 


\subsection{Preparation of experiment}

All experiments were performed over 90-day-old concrete. At first, the ends of concrete specimens were ground aiming to achieve parallelism between the two ends of the cylinders. The bonded regions and the unbonded regions (see Figure 1) were delimited in the concrete with a permanent marker pen. These regions were sanded with a micro rotary tool in order to partially expose aggregates of concrete and to obtain a small surface irregularity. Water was thrown on the side of specimens to eliminate dust generated in the previous step. After a few hours, silicone was applied in the outside of the bonded and unbonded regions delimiting the perimeter, and inside the unbonded zone. Silicone prevents adhesion between resin and concrete.

The dry carbon fiber and the saturating epoxy resin presented in the "Material properties" section were used in the application of wet lay-up FRP system. A resin layer of 0.4 kilogram per square meter consumption was uniformly applied on the surface of the bonded and unbonded zones with a spatula. The carbon fiber was firmly pressed on the substrate with a metal-groove roller, which is also used to eliminate the entrapped air. After that, another resin layer with the same consumption was applied on the fiber. The experiments were performed after seven days of application of FRP.

A metallic apparatus was produced for direct tensile experiments in cylindrical specimens. This apparatus contains one metal shaft, a load cell of $100 \mathrm{KN}$, metal parts to allow a simply supported connection at the point of loading, plates, and metal rings. Three pairs of metal rings, with internal diameters of $150 \mathrm{~mm}, 100 \mathrm{~mm}$, and $50 \mathrm{~mm}$, were produced. In these pairs, each ring is $75 \mathrm{~mm}$ high, $50 \mathrm{~mm}$ high, and $22 \mathrm{~mm}$ high, respectively. The pair of rings with an inner diameter of 50 $\mathrm{mm}$ is inserted into the pair of rings with an inner diameter of $100 \mathrm{~mm}$, during experiments with $50 \mathrm{~mm} \times 100 \mathrm{~mm}$ specimens. The apparatus is shown in Figures 3,4 and 5. The set (concrete specimens and FRP sheets) was fixed in the plates and metal rings with screws and epoxy-based adhesive. The experiment was performed three days after application of adhesive.

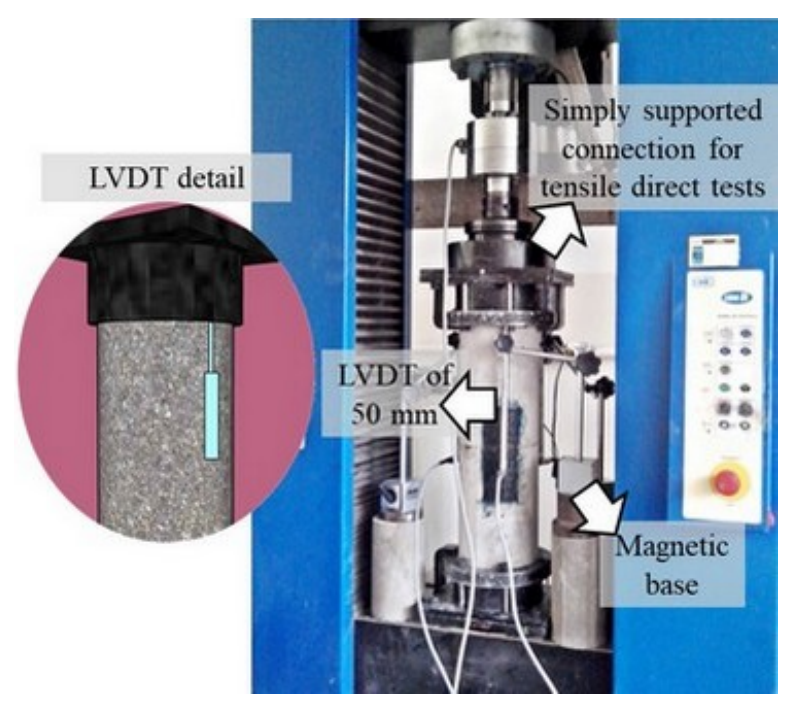

Figure 3. Apparatus with internal diameter of $150 \mathrm{~mm}$ for conducting direct tensile tests.

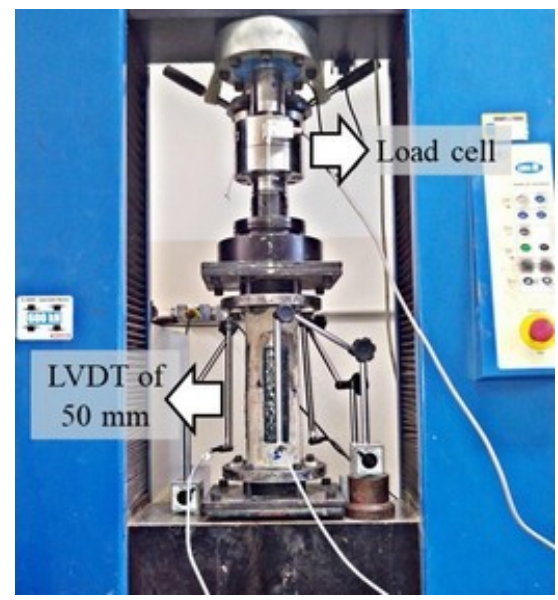

Figure 4. Apparatus with internal diameter of $100 \mathrm{~mm}$ for conducting direct tensile tests. 


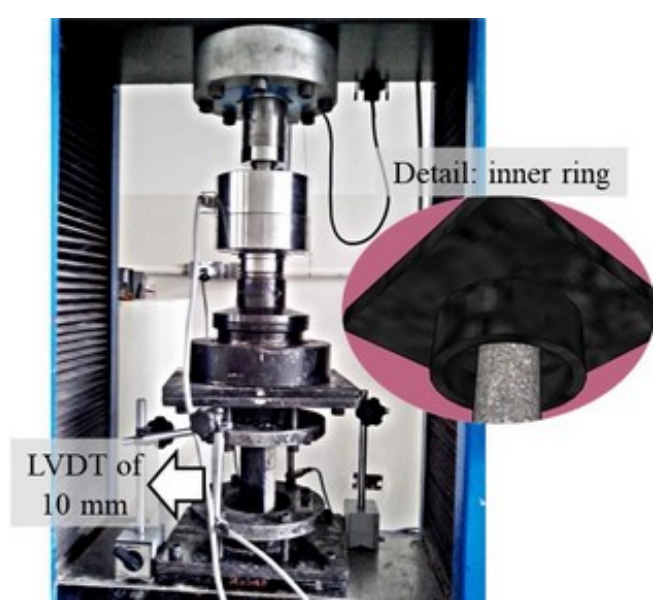

Figure 5. Apparatus with internal diameter of $50 \mathrm{~mm}$ for conducting direct tensile tests.

Three linear variable differential transformers (LVDT) were used in each experiment to measure of vertical displacement. Each LVDT was placed parallel to the center of an FRP sheet, in the upper part of the metallic apparatus, in the vertical direction. In experiments with $50 \mathrm{~mm} \times 100 \mathrm{~mm}$ specimens, each LVDT was placed on the upper metallic plate (see Figure 5). In experiments with $100 \mathrm{~mm} \times 200 \mathrm{~mm}$ specimens and $150 \mathrm{~mm} \times 300 \mathrm{~mm}$ specimens, each LVDT was placed on the upper metallic ring (see Figures 3 and 4).

\subsection{Application of the Chen and Teng's model (2001)}

In this study, some considerations were adopted to compare the experimental results (Santos et al. [25] methodology) to the force values predicted using the Chen and Teng's model [40], according to Equations 5, 6 and 7.

$$
L=L 1
$$

$b_{c}=2 \pi R=\pi D$

$b_{p}=3 W$

where $L=$ bond length $(\mathrm{mm}) ; L 1=$ bond length - upper region $(\mathrm{mm}) ; b_{c}=$ width of concrete member $(\mathrm{mm})$; $R=$ cylindrical specimen radius $(\mathrm{mm}) ; D=$ diameter of concrete cylindrical specimens $(\mathrm{mm}) ; b_{p}=$ width of bonded FRP plates (mm); and $W=$ width of an FRP sheet in the direct tensile test (mm).

\section{EXPERIMENTAL PROGRAM}

Three dimensions of cylindrical specimens (diameter $\times$ height) were used for analysis of size effect: $50 \mathrm{~mm} \times$ $100 \mathrm{~mm}, 100 \mathrm{~mm} \times 200 \mathrm{~mm}$, and $150 \mathrm{~mm} \times 300 \mathrm{~mm}$, as shown in Figure 6 . The influence of specimen size on the debonding between concrete and FRP was evaluated for ten different geometries of FRP. These geometries are listed in Table 2. In all experiments, the length of unbonded zone (LN) was $40 \mathrm{~mm}: 20 \mathrm{~mm}$ on the upper specimen and $20 \mathrm{~mm}$ on the lower specimen. Santos et al. [25] defined this length of the unbonded zone by means of two-dimensional and three-dimensional numerical simulations of the stress distribution along the interface. 


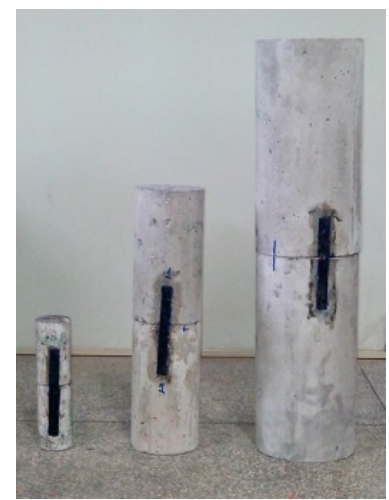

Figure 6. Variation in specimen dimensions.

Table 2. Experimental program.

\begin{tabular}{|c|c|c|c|c|}
\hline $\begin{array}{l}\text { Geometry } \\
\text { code }\end{array}$ & FRP geometry & $\begin{array}{l}50 \mathrm{~mm} \times 100 \mathrm{~mm} \\
\text { cylindrical specimen }\end{array}$ & $\begin{array}{l}100 \mathrm{~mm} \times 200 \mathrm{~mm} \\
\text { cylindrical specimen }\end{array}$ & $\begin{array}{l}150 \mathrm{~mm} \times 300 \mathrm{~mm} \\
\text { cylindrical specimen }\end{array}$ \\
\hline \multirow{3}{*}{ G01 } & $\mathrm{L} 1=33 \mathrm{~mm}$ & & & \\
\hline & $\mathrm{L} 2=50 \mathrm{~mm}$ & $\mathrm{X}$ & $\mathrm{X}$ & $\mathrm{X}$ \\
\hline & $\mathrm{W}=10 \mathrm{~mm}$ & & & \\
\hline \multirow{3}{*}{ G02 } & $\mathrm{L} 1=33 \mathrm{~mm}$ & & & \\
\hline & $\mathrm{L} 2=50 \mathrm{~mm}$ & $\mathrm{X}$ & $\mathrm{X}$ & $\mathrm{X}$ \\
\hline & $\mathrm{W}=20 \mathrm{~mm}$ & & & \\
\hline \multirow{3}{*}{ G03 } & $\mathrm{L} 1=33 \mathrm{~mm}$ & & & \\
\hline & $\mathrm{L} 2=50 \mathrm{~mm}$ & & $\mathrm{X}$ & $\mathrm{X}$ \\
\hline & $\mathrm{W}=40 \mathrm{~mm}$ & & & \\
\hline \multirow{3}{*}{ G04 } & $\mathrm{L} 1=33 \mathrm{~mm}$ & & & \\
\hline & $\mathrm{L} 2=50 \mathrm{~mm}$ & & $\mathrm{X}$ & $\mathrm{X}$ \\
\hline & $\mathrm{W}=60 \mathrm{~mm}$ & & & \\
\hline \multirow{3}{*}{ G05 } & $\mathrm{L} 1=33 \mathrm{~mm}$ & & & \\
\hline & $\mathrm{L} 2=50 \mathrm{~mm}$ & & $X$ & $\mathrm{X}$ \\
\hline & $\mathrm{W}=80 \mathrm{~mm}$ & & & \\
\hline \multirow{3}{*}{ G06 } & $\mathrm{L} 1=50 \mathrm{~mm}$ & & & \\
\hline & $\mathrm{L} 2=75 \mathrm{~mm}$ & & $\mathrm{X}$ & $\mathrm{X}$ \\
\hline & $\mathrm{W}=10 \mathrm{~mm}$ & & & \\
\hline \multirow{3}{*}{ G07 } & $\mathrm{L} 1=50 \mathrm{~mm}$ & & & \\
\hline & $\mathrm{L} 2=75 \mathrm{~mm}$ & & $\mathrm{X}$ & $\mathrm{X}$ \\
\hline & $\mathrm{W}=20 \mathrm{~mm}$ & & & \\
\hline \multirow{3}{*}{ G08 } & $\mathrm{L} 1=50 \mathrm{~mm}$ & & & \\
\hline & $\mathrm{L} 2=75 \mathrm{~mm}$ & & $\mathrm{X}$ & $\mathrm{X}$ \\
\hline & $\mathrm{W}=40 \mathrm{~mm}$ & & & \\
\hline \multirow{3}{*}{ G09 } & $\mathrm{L} 1=50 \mathrm{~mm}$ & & & \\
\hline & $\mathrm{L} 2=75 \mathrm{~mm}$ & & $\mathrm{X}$ & $\mathrm{X}$ \\
\hline & $\mathrm{W}=60 \mathrm{~mm}$ & & & \\
\hline \multirow{5}{*}{ G10 } & $\mathrm{L} 1=50 \mathrm{~mm}$ & & & \\
\hline & $\mathrm{L} 2=75 \mathrm{~mm}$ & & $\mathrm{X}$ & $\mathrm{X}$ \\
\hline & $\mathrm{W}=80 \mathrm{~mm}$ & & & \\
\hline & & 2 experiments & 10 experiments & 10 experiments \\
\hline & & 4 specimens & 20 specimens & 20 specimens \\
\hline
\end{tabular}




\section{RESULTS AND DISCUSSIONS}

\subsection{Failure modes}

Twenty-two experiments were conducted. Two failure modes were observed in the experiments: failure in concrete specimens and debonding in the interface between FRP and concrete. Figures 7 and 8 illustrate failure modes. Debonding failures were observed in $63.6 \%$ of these experiments. Tests with concrete tensile failure are not valid when analyzing the interface between concrete and FRP, and they are presented only for a verification of the maximum stress values. In the experiments with concrete failure, ruptures were very close to the end of the metal ring in which specimen was inserted (see Figure 8). There is probably a stress concentration at this place. For this reason, it is intended to make a stress analysis in future studies. The metallic apparatus produced in this work and the methodology of Santos et al. [25] will be considered in stress analysis.
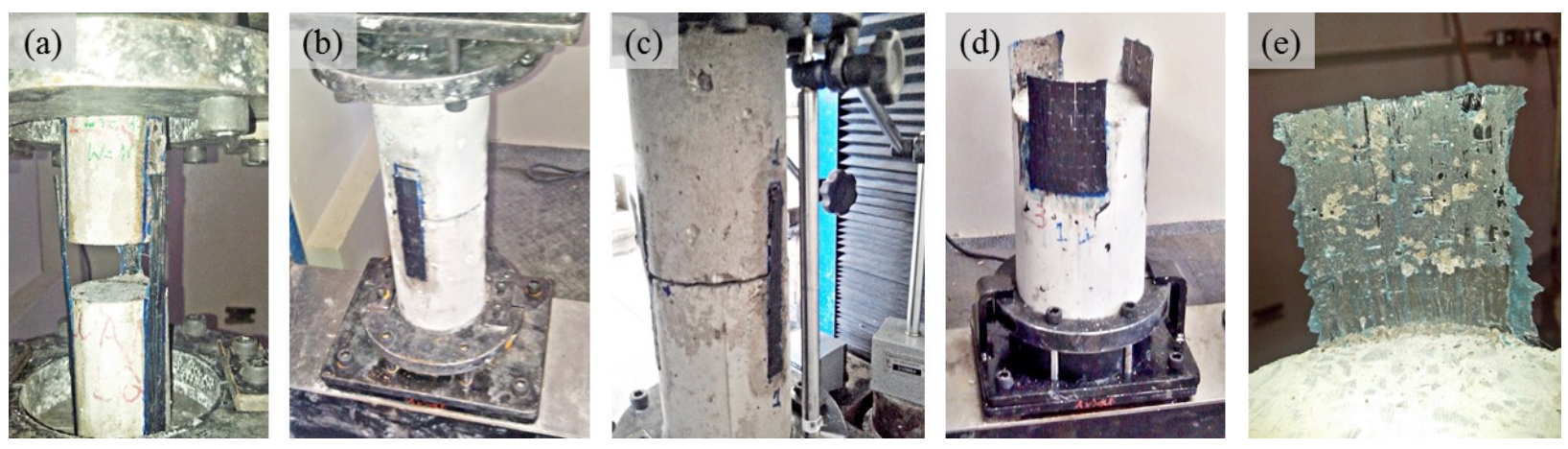

Figure 7. Experiments with debonding failure between concrete and FRP: a) FRP geometry G01 and $50 \mathrm{~mm} \times 100 \mathrm{~mm}$ specimens; b) FRP geometry G02 and $100 \mathrm{~mm} \times 200 \mathrm{~mm}$ specimens; c) FRP geometry G01 and $100 \mathrm{~mm} \times 200 \mathrm{~mm}$ specimens;

d) FRP geometry G05 and $150 \mathrm{~mm} \times 300 \mathrm{~mm}$ specimens; e) FRP geometry G09 and $150 \mathrm{~mm} \times 300 \mathrm{~mm}$ specimens.
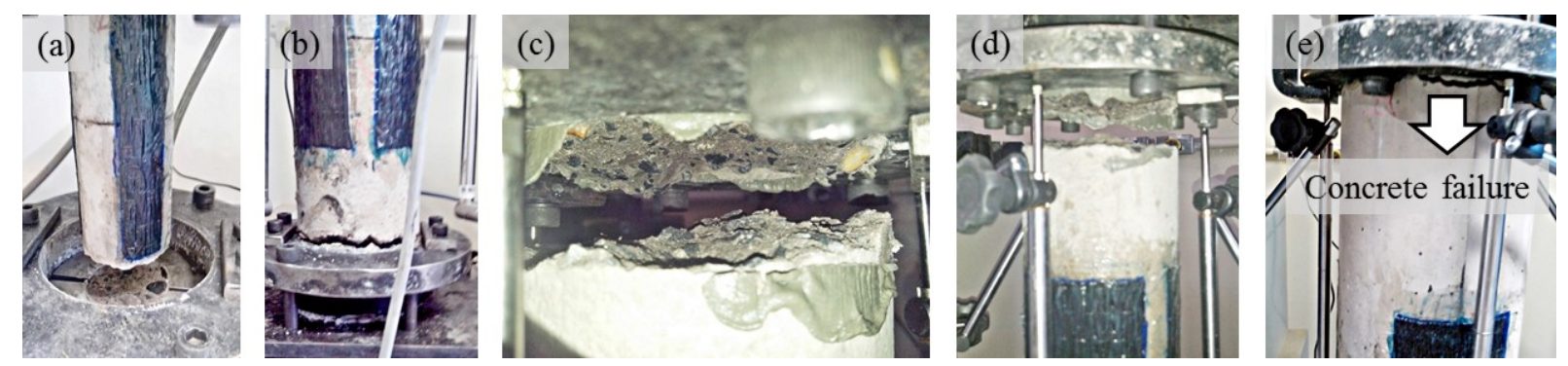

Figure 8. Experiments with concrete failure: a) FRP geometry G02 and $50 \mathrm{~mm} \times 100 \mathrm{~mm}$ specimens; b) FRP geometry G05 and $100 \mathrm{~mm} \times 200 \mathrm{~mm}$ specimens; c) FRP geometry G08 and $100 \mathrm{~mm} \times 200 \mathrm{~mm}$ specimens; d) FRP geometry G10 and $100 \mathrm{~mm} \times$ $200 \mathrm{~mm}$ specimens; e) FRP geometry G10 and $150 \mathrm{~mm} \times 300 \mathrm{~mm}$ specimens.

The failure modes in each experiment are listed in Table 3. This table also contains values of maximum tensile force (Pmax) reached in each experiment, values of normal tensile stress $(\sigma)$ on the concrete relating to this force, and values of maximum shear stress $(\tau)$ at the interface between concrete and FRP. The stress $\sigma$ is the maximum force divided by the cross-sectional area of concrete specimen, and the stress $\tau$ is the maximum force divided by the upper adhesion area of the three FRP sheets. In case of interface failures, shear stress refers to stress reached in debonding the first FRP sheet. Figure 9 shows a comparison between the maximum force values in experiments with debonding failure and the force values predicted by Chen and Teng's model, with considerations in the section "Application of the Chen and Teng's model". The experimental results are in good agreement with the model. 
Table 3. Failure mode, maximum tensile force (Pmax), normal tensile stress on the concrete $(\sigma)$, and shear stress at the interface between concrete and $\operatorname{FRP}(\tau)$.

\begin{tabular}{|c|c|c|c|}
\hline Geometry code & $\begin{array}{c}50 \mathrm{~mm} \times 100 \mathrm{~mm} \text { cylindrical } \\
\text { specimen }\end{array}$ & $\begin{array}{c}100 \mathrm{~mm} \times 200 \mathrm{~mm} \text { cylindrical } \\
\text { specimen }\end{array}$ & $\begin{array}{c}150 \mathrm{~mm} \times 300 \mathrm{~mm} \text { cylindrical } \\
\text { specimen }\end{array}$ \\
\hline \multirow{4}{*}{ G01 } & Debonding & Debonding & Debonding \\
\hline & $P \max =4.30 \mathrm{KN}$ & $P \max =4.60 \mathrm{KN}$ & $P \max =4.51 \mathrm{KN}$ \\
\hline & $\sigma=2.19 \mathrm{MPa}$ & $\sigma=0.59 \mathrm{MPa}$ & $\sigma=0.25 \mathrm{MPa}$ \\
\hline & $\tau=4.35 \mathrm{MPa}$ & $\tau=4.65 \mathrm{MPa}$ & $\tau=4.55 \mathrm{MPa}$ \\
\hline \multirow{4}{*}{ G02 } & Concrete failure & Debonding & Debonding \\
\hline & $\mathrm{Pmax}=4.74 \mathrm{KN}$ & $P \max =9.12 \mathrm{KN}$ & $\operatorname{Pmax}=8.90 \mathrm{KN}$ \\
\hline & $\sigma=2.41 \mathrm{MPa}$ & $\sigma=1.16 \mathrm{MPa}$ & $\sigma=0.50 \mathrm{MPa}$ \\
\hline & $\tau=2.39 \mathrm{MPa}$ & $\tau=4.60 \mathrm{MPa}$ & $\tau=4.49 \mathrm{MPa}$ \\
\hline \multirow{4}{*}{ G03 } & & Concrete failure & Debonding \\
\hline & & $\mathrm{Pmax}=10.92 \mathrm{KN}$ & $P \max =17.92 \mathrm{KN}$ \\
\hline & & $\sigma=1.39 \mathrm{MPa}$ & $\sigma=1.01 \mathrm{MPa}$ \\
\hline & & $\tau=2.76 \mathrm{MPa}$ & $\tau=4.52 \mathrm{MPa}$ \\
\hline \multirow{4}{*}{ G04 } & & Concrete failure & Debonding \\
\hline & & $\operatorname{Pmax}=11.99 \mathrm{KN}$ & $P \max =11.75 \mathrm{KN}$ \\
\hline & & $\sigma=1.53 \mathrm{MPa}$ & $\sigma=0.66 \mathrm{MPa}$ \\
\hline & & $\tau=2.02 \mathrm{MPa}$ & $\tau=1.98 \mathrm{MPa}$ \\
\hline \multirow{4}{*}{ G05 } & & Concrete failure & Debonding \\
\hline & & $P \max =9.21 \mathrm{KN}$ & $P \max =22.47 \mathrm{KN}$ \\
\hline & & $\sigma=1.17 \mathrm{MPa}$ & $\sigma=1.27 \mathrm{MPa}$ \\
\hline & & $\tau=1.16 \mathrm{MPa}$ & $\tau=2.84 \mathrm{MPa}$ \\
\hline \multirow{4}{*}{ G06 } & & Debonding & Debonding \\
\hline & & $P \max =6.30 \mathrm{KN}$ & $P \max =6.15 \mathrm{KN}$ \\
\hline & & $\sigma=0.80 \mathrm{MPa}$ & $\sigma=0.35 \mathrm{MPa}$ \\
\hline & & $\tau=4.20 \mathrm{MPa}$ & $\tau=4.10 \mathrm{MPa}$ \\
\hline \multirow{4}{*}{ G07 } & & Debonding & Debonding \\
\hline & & $P \max =8.95 \mathrm{KN}$ & $P \max =10.47 \mathrm{KN}$ \\
\hline & & $\sigma=1.14 \mathrm{MPa}$ & $\sigma=0.59 \mathrm{MPa}$ \\
\hline & & $\tau=2.98 \mathrm{MPa}$ & $\tau=3.49 \mathrm{MPa}$ \\
\hline \multirow{4}{*}{ G08 } & & Concrete failure & Debonding \\
\hline & & $P \max =10.61 \mathrm{KN}$ & $P \max =19.64 \mathrm{KN}$ \\
\hline & & $\sigma=1.35 \mathrm{MPa}$ & $\sigma=1.11 \mathrm{MPa}$ \\
\hline & & $\tau=1.77 \mathrm{MPa}$ & $\tau=3.27 \mathrm{MPa}$ \\
\hline \multirow{4}{*}{ G09 } & & Concrete failure & Debonding \\
\hline & & $\operatorname{Pmax}=14.84 \mathrm{KN}$ & $P \max =29.69 \mathrm{KN}$ \\
\hline & & $\sigma=1.89 \mathrm{MPa}$ & $\sigma=1.68 \mathrm{MPa}$ \\
\hline & & $\tau=1.65 \mathrm{MPa}$ & $\tau=3.30 \mathrm{MPa}$ \\
\hline \multirow{4}{*}{ G10 } & & Concrete failure & Concrete failure \\
\hline & & $P \max =13.60 \mathrm{KN}$ & $P \max =34.23 \mathrm{KN}$ \\
\hline & & $\sigma=1.73 \mathrm{MPa}$ & $\sigma=1.94 \mathrm{MPa}$ \\
\hline & & $\tau=1.13 \mathrm{MPa}$ & $\tau=2.85 \mathrm{MPa}$ \\
\hline
\end{tabular}

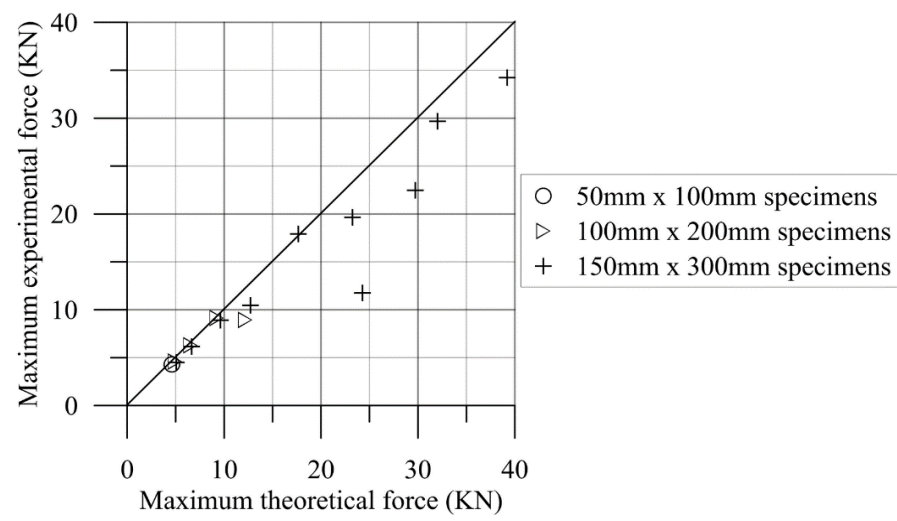

Figure 9. Comparison between experimental maximum force and theoretical maximum force. 
In Table 3, in some FRP geometries, it can be observed that concrete failure occurred in experiments with smaller specimens $(50 \mathrm{~mm} \times 100 \mathrm{~mm}$ and $100 \mathrm{~mm} \times 200 \mathrm{~mm})$, while debonding failure was verified in experiments with larger specimens $(150 \mathrm{~mm} \times 300 \mathrm{~mm})$. Cross-sectional area of $150 \mathrm{~mm} \times 300 \mathrm{~mm}$ cylinders is larger than the cross-sectional area of the smaller specimens, and the concrete of all specimens had the same mixing ratio. Therefore, a higher tensile force can be applied in experiments with $150 \mathrm{~mm} \times 300 \mathrm{~mm}$ specimens before reaching the tensile strength of the concrete, compared to experiments with $50 \mathrm{~mm} \times 100 \mathrm{~mm}$ and $100 \mathrm{~mm} \times 200 \mathrm{~mm}$ concrete specimens. Shear stress required to cause the composite debonding was not reached in experiments with concrete failure because concrete reached first the normal tensile strength.

In general, failure mode has been altered to concrete failure as the strengthening perimeter increased to a same specimen size. Therefore, concrete becomes the "weakest element" of the system as the perimeter of adhered FRP increases significantly, and no longer the interface between concrete and FRP. This shows that FRP strengthening in concrete structure is efficient.

\subsection{Considerations on experiments with concrete failure}

Some initial excerpts from plot of load versus displacement in experiments are presented in this section and in the next section. In experiments with debonding failures, the initial excerpt represents the behavior regarding the debonding of the first FRP sheet. The three LVDT presented very similar behavior in each experiment. For this reason, displacement represented in each graph is the average of the three values obtained in each test.

A stiffness comparison between two experiments with the same FRP geometry and different specimen dimensions is made in Figure 10, in which failure was due to concrete failure. A smaller force was reached in the experiment with $100 \mathrm{~mm} \times 200 \mathrm{~mm}$ cylindrical specimens, in comparison with the experiment with 150 $\mathrm{mm} \times 300 \mathrm{~mm}$ specimens. However, the slopes of the curves were very similar in the two cases. As a curiosity, two graphs (Figure 11) are presented, in which experiments with the same FRP geometry, different dimensions of specimens, and different failure modes were considered. In these cases, the slopes of graphs were very similar in the two failure modes for the same FRP geometry, especially at the initial excerpt of load versus displacement curves. There is a significant reduction in stiffness near the failure in the curve of experiment with concrete rupture, but the initial excerpt of this graph was very similar to the curve of the experiment with debonding failure.

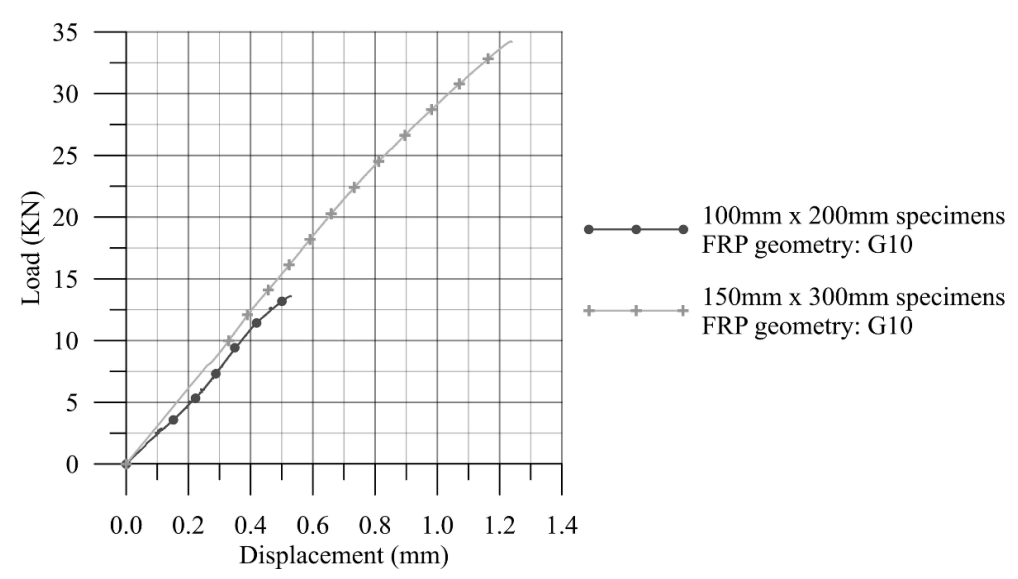

Figure 10. Plot of load versus displacement to the peak in experiments with the same FRP geometry and concrete failure. 

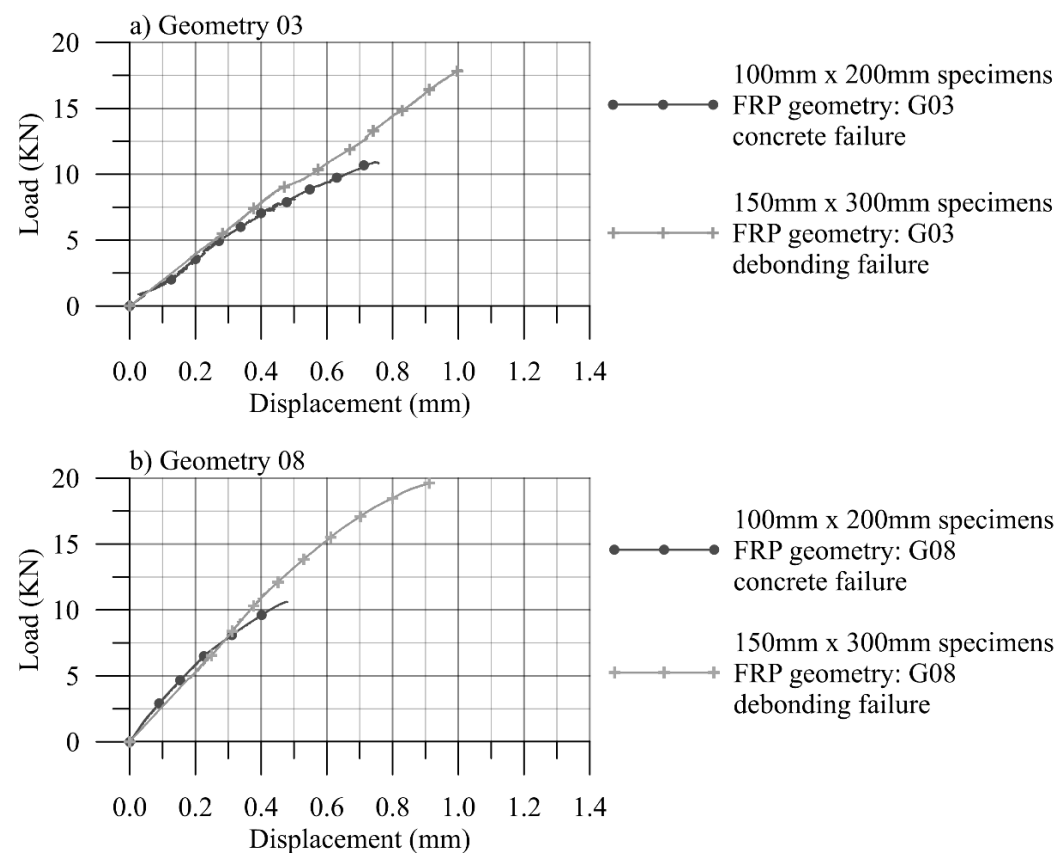

Figure 11. Plot of load versus displacement to the peak in experiments with the same FRP geometry and different failure modes.

\subsection{Size effect on interface failure between concrete and FRP}

In this section, the cases in which debonding failure was observed in experiments with different dimensions of concrete specimens and the same dimensions of FRP sheets are analyzed. Thus, experiments with the FRP geometries G01, G02, G06 and G07 are considered. The maximum shear stress values in these experiments are shown in Figure 12. Table 3 contains the maximum tensile force (Pmax) in these experiments. The values of maximum force and shear stress were very similar in experiments with debonding failure, different dimensions of specimens, and same FRP geometry. The differences in maximum shear strength in relation to the experiments with $150 \mathrm{~mm} \times 300 \mathrm{~mm}$ (the specimens proposed in the methodology of Santos et al. [25]) are: $4.40 \%$ decrease for $50 \mathrm{~mm} \times 100 \mathrm{~mm}$ specimens and G01 geometry, $2.20 \%$ increase for $100 \mathrm{~mm} \times 200 \mathrm{~mm}$ specimens and G01 geometry, $2.45 \%$ increase for $100 \mathrm{~mm} \times$ $200 \mathrm{~mm}$ specimens and G02 geometry, $2.43 \%$ increase for $100 \mathrm{~mm} \times 200 \mathrm{~mm}$ specimens and G06 geometry, and $14.61 \%$ decrease for $100 \mathrm{~mm} \times 200 \mathrm{~mm}$ specimens and G07 geometry.

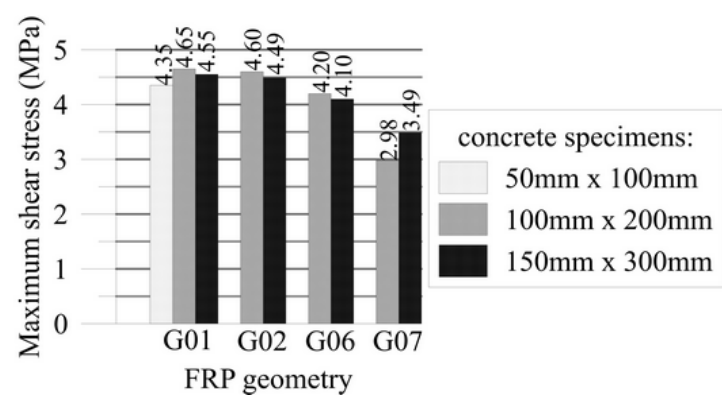

Figure 12. Comparison of the maximum shear stress in the debonding failure in experiments with different specimen dimensions.

The greatest difference in shear stress and maximum force values, in experiments with the same FRP geometry and debonding failure, was registered in the experiments with G07 geometry (14.61\% decrease in maximum shear strength for $100 \mathrm{~mm} \times 200 \mathrm{~mm}$ specimens compared to the result with $150 \mathrm{~mm} \times 300 \mathrm{~mm}$ specimens). In experiments with debonding failure, there is a tendency for a maximum force to increase when the width is the same and bond length augments, as shown in Figure 13. This was verified in experiments with $100 \mathrm{~mm} \times 200 \mathrm{~mm}$ and $150 \mathrm{~mm} \times 300 \mathrm{~mm}$ specimens. However, while increasing the bond length, the maximum force decreased in the experiments with 
$100 \mathrm{~mm} \times 200 \mathrm{~mm}$ cylinders and width of $20 \mathrm{~mm}$ (G02 and G07 geometries). Therefore, according to the tendency of the maximum force values (Figure 13), a greater force should have been reached in the experiment with $100 \mathrm{~mm} \times 200 \mathrm{~mm}$ specimens and G07 geometry, and consequently a greater maximum shear strength should have been reached. Some reason may have caused the drop of the maximum force in debonding in the experiment with $100 \mathrm{~mm} \times 200 \mathrm{~mm}$ specimens and G07 geometry. The reasons for this reduction may be the use of specimens with a defect, error in preparation of the resin, deficiency in the fiber debonding process (for example, non-application of required pressure), among others. In addition, a readjustment occurred in the position of the parts of the metallic apparatus during this experiment, and this readjustment may have influenced the maximum strength.

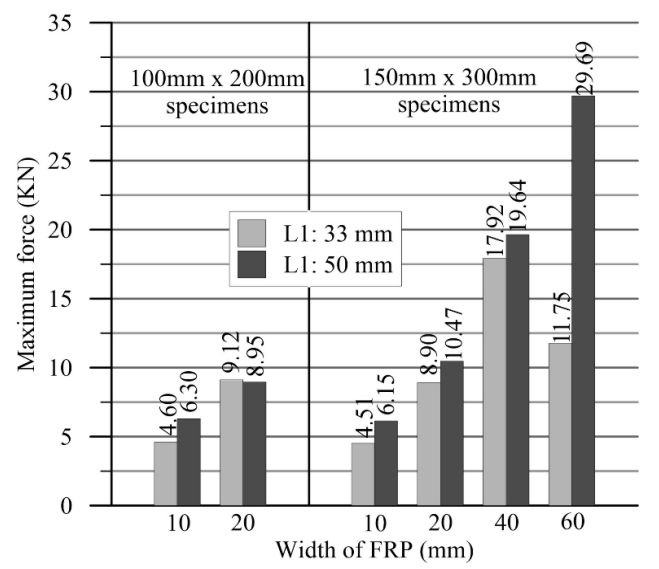

Figure 13. Influence of the bond length on the maximum debonding force.

Finally, the influence of the specimen size on the plot of load versus displacement in experiments with debonding failure is evaluated in Figure 14. Readjustments in the position were observed in some experiments, in parts that were not graphically presented in Figure 14. There is no significant influence on stiffness due to change in the size of concrete specimens.
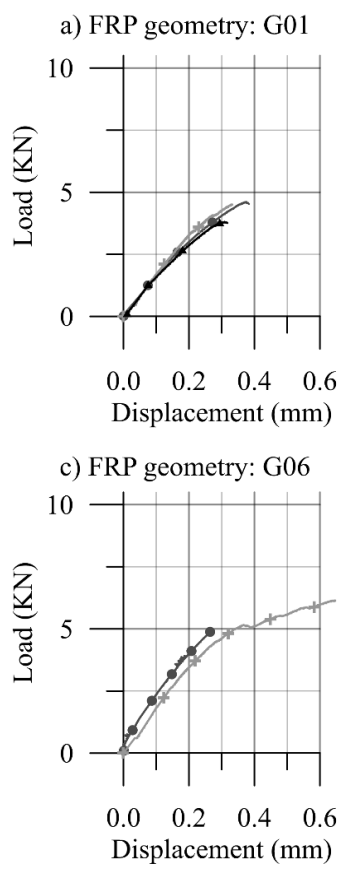

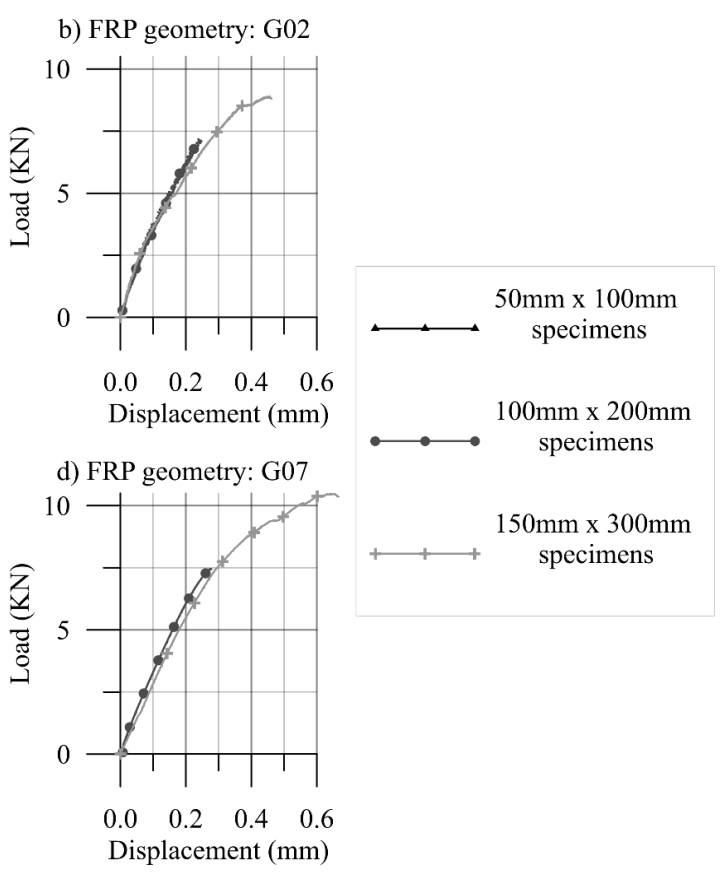

Figure 14. Initial portions of load versus displacement graphs in experiments with different dimensions of concrete specimens, the same FRP geometry, and debonding failure between concrete and FRP. 


\section{CONCLUSIONS}

In this study, the test for evaluating the debonding between FRP and concrete by means of direct tensile on concrete cylinders was carried out on specimens of different dimensions for the evaluation of the size effect. Two failure modes were observed in the experiments: debonding between the two materials and failure in concrete specimens (when the concrete's tensile strength was reached). In this methodology, concrete failure is not desirable, because the test is done for evaluate the debonding phenomenon. In experiments with debonding failure, the size of concrete specimens has no significant influence on maximum force (Pmax), shear stress to the peak, and stiffness in debonding between concrete and FRP. The interface collapse was found in experiments with small specimens $(50 \mathrm{~mm} \times 100 \mathrm{~mm}$ and $100 \mathrm{~mm} \times$ $200 \mathrm{~mm}$ ) with results similar to those obtained in experiments with $150 \mathrm{~mm} \times 300 \mathrm{~mm}$ specimens. In other words, analysis of the debonding in experiments with small cylindrical concrete specimens also leads to good results. Nevertheless, the use of smaller specimens for interface collapse analysis is limited because the failure often occurs in the concrete (the concrete reaches its normal stress capacity with a lower value of tensile force). Since its cross section is larger, a greater tensile force can be applied to $150 \mathrm{~mm} \times 300 \mathrm{~mm}$ specimens, compared to smaller specimens. For the same FRP geometry, small concrete cylinders are more susceptible to concrete failure. Thus, the use of larges specimens of concrete (for example, $150 \mathrm{~mm} \times 300 \mathrm{~mm}$ cylinders) is recommended in future studies with the same methodology of this paper.

\section{ACKNOWLEDGEMENTS}

The authors gratefully acknowledge CAPES (Coordenação de Aperfeiçoamento de Pessoal de Nível Superior) and FAPEMIG (Fundação de Amparo à Pesquisa do Estado de Minas Gerais) for financial support.

\section{REFERENCES}

[1] A. K. El-Sayed and K. Soudki, "Evaluation of shear design equations of concrete beams with FRP reinforcement," J. Compos. Constr., vol. 15, no. 1, pp. 9-20, 2011, http://dx.doi.org/10.1061/(ASCE)CC.1943-5614.0000158.

[2] R. H. Haddad, R. Z. Al-Rousan, and B. K. Al-Sedyiri, "Repair of shear-deficient and sulfate-damaged reinforced concrete beams using FRP composites," Eng. Struct., vol. 56, pp. 228-238, 2013, http://dx.doi.org/10.1016/j.engstruct.2013.05.007.

[3] A. Carpinteri, P. Cornetti, G. Lacidogna, and M. Paggi, "Towards a unified approach for the analysis of failure modes in FRPretrofitted concrete beams," Adv. Struct. Eng., vol. 12, no. 5, pp. 715-729, 2009, http://dx.doi.org/10.1260/136943309789867863.

[4] K. Lang and A. Schumacher, "Strengthening of mansory and metallic structures," in The International Handbook of FRP Composites in Civil Engineering, M. Zoghi, Ed., Boca Raton: CRC Press, 2014, ch. 17, pp. 293-312.

[5] A. Manalo, C. Sirimanna, W. Karunasena, L. McGarva, and P. Falzon, "Pre-impregnated carbon fibre reinforced composite system for patch repair of steel I-beams," Constr. Build. Mater., vol. 105, pp. 365-376, 2016, http://dx.doi.org/10.1016/j.conbuildmat.2015.12.172.

[6] O. Rabinovitch, "Dynamic debonding in concrete beams strengthened with composite materials," Int. J. Solids Struct., vol. 49, no. 26, pp. 3641-3658, 2012, http://dx.doi.org/10.1016/j.ijsolstr.2012.07.025.

[7] T. J. Stratford and J. F. Chen, "Designing for tapers and defects in FRP-strengthened metallic structures," in Int. Symp. Bond Behav. FRP Struct. BBFS, 2005, pp. 453-458. [Online]. Available: http://www.research.ed.ac.uk/portal/files/4127274/c2005_1.pdf

[8] V. Gattulli, E. Lofrano, A. Paolone, and G. Pirolli, "Performances of FRP reinforcements on masonry buildings evaluated by fragility curves," Comput. Struc., vol. 190, pp. 150-161, 2017, http://dx.doi.org/10.1016/j.compstruc.2017.05.012.

[9] B. Pantò, F. Cannizzaro, S. Caddemi, I. Caliò, C. Chácara, and P. B. Lourenço, "Nonlinear modelling of curved masonry structures after seismic retrofit through FRP reinforcing," Buildings, vol. 7, no. 3, pp. 79, 2017, http://dx.doi.org/10.3390/buildings7030079.

[10] D. Lau, Q. Qiu, A. Zhou, and C. L. Chow, "Long term performance and fire safety aspect of FRP composites used in building structures," Constr. Build. Mater., vol. 126, pp. 573-585, 2016, http://dx.doi.org/10.1016/j.conbuildmat.2016.09.031.

[11] K. U. Schober, A. M. Harte, R. Kliger, R. Jockwer, Q. Xu, and J. F. Chen, "FRP reinforcement of timber structures," Constr. Build. Mater., vol. 97, pp. 106-118, 2015, http://dx.doi.org/10.1016/j.conbuildmat.2015.06.020.

[12] F. Greco, L. Leonetti, and P. Lonetti, "A two-scale failure analysis of composite materials in presence of fiber/matrix crack initiation and propagation," Compos. Struct., vol. 95, pp. 582-597, 2013, http://dx.doi.org/10.1016/j.compstruct.2012.08.035.

[13] H. R. E. Houachine, Z. Sereir, B. Kerboua, and K. Hadjazi, "Combined cohesive-bridging zone model for prediction of the debonding between the FRP and concrete beam interface with effect of adherend shear deformations," Compos., Part B Eng., vol. 45, no. 1, pp. 871-880, 2013, http://dx.doi.org/10.1016/j.compositesb.2012.08.009.

[14] L. Biolzi, C. Ghittoni, R. Fedele, and G. Rosati, "Experimental and theoretical issues in FRP-concrete bonding," Constr. Build. Mater., vol. 41, pp. 182-190, 2013, http://dx.doi.org/10.1016/j.conbuildmat.2012.11.082. 
[15] M. M. Fayyadh and H. A. Razak, "Analytical and experimental study on repair effectiveness of CRFP sheets for RC beams," J. Civ. Eng. Manag., vol. 20, no. 1, pp. 21-31, 2013, http://dx.doi.org/10.3846/13923730.2013.799095.

[16] J. G. Teng, J. F. Chen, S. T. Smith, and L. Lam, FRP Strengthened RC Structures. Chichester: John Wiley \& Sons, 2002.

[17] M. R. Aram, C. Czaderski, and M. Motavalli, "Debonding failure modes of flexural FRP-strengthened RC beams," Compos., Part B Eng., vol. 39, no. 5, pp. 826-841, 2008, http://dx.doi.org/10.1016/j.compositesb.2007.10.006.

[18] J. A. O. Barros, S. J. E. Dias, and J. L. T. Lima, "Efficacy of CFRP-based techniques for the flexural and shear strengthening of concrete beams," Cement Concr. Compos., vol. 29, no. 3, pp. 203-217, 2007, http://dx.doi.org/10.1016/j.cemconcomp.2006.09.001.

[19] H. C. Biscaia, M. A. G. Silva, and C. Chastre, "An experimental study of GFRP-to-concrete interfaces submitted to humidity cycles," Compos. Struct., vol. 110, no. 1, pp. 354-368, 2014, http://dx.doi.org/10.1016/j.compstruct.2013.12.014.

[20] J. Yao and J. G. Teng, "Plate end debonding in FRP-plated RC beams-I: Experiments," Eng. Struct., vol. 29, no. 10, pp. 2457-2471, 2007, http://dx.doi.org/10.1016/j.engstruct.2006.11.022.

[21] H. Toutanji, M. Han, and E. Ghorbel, "Interfacial bond strength characteristics of FRP and RC substrate," J. Compos. Constr., vol. 16, no. 1, pp. 35-46, 2012, http://dx.doi.org/10.1061/(ASCE)CC.1943-5614.0000236.

[22] T. Mohammadi, "Failure mechanisms and key parameters of FRP debonding from cracked beams," Ph.D. dissertation, Marquette Univ., Milwaukee, Wis., 2014.

[23] F. M. Mukhtar and R. M. Faysal, "A review of test methods for studying the FRP-concrete interfacial bond behavior," Constr. Build. Mater., vol. 169, pp. 877-887, Apr 2018, http://dx.doi.org/10.1016/j.conbuildmat.2018.02.163.

[24] A. Serbescu, M. Guadagnini, and K. Pilakoutas, "Standardised double-shear test for determining bond of FRP to concrete and corresponding model development," Compos., Part B Eng., vol. 55, pp. 277-297, Dec 2013, http://dx.doi.org/10.1016/j.compositesb.2013.06.019.

[25] A. C. Santos, T. N. Bittencourt, and R. Gettu, "Experimental analysis of the interface between CFRP and concrete through use of cylindrical specimens," in 6th Int. Symp. FRP Reinf. Concr. Struct., 2003, pp. 173-182. http://dx.doi.org/10.1142/9789812704863_0014.

[26] E. Ben Dror and O. Rabinovitch, "Size effect in the debonding failure of FRP strengthened beams," Eng. Fract. Mech., vol. 156, pp. 161-181, May 2016, http://dx.doi.org/10.1016/j.engfracmech.2016.02.007.

[27] S. Moallemi, S. Pietruszczak, and Z. Mróz, "Deterministic size effect in concrete structures with account for chemo-mechanical loading," Comput. Struc., vol. 182, pp. 74-86, 2017, http://dx.doi.org/10.1016/j.compstruc.2016.10.003.

[28] G. Muciaccia, G. Rosati, and G. Di Luzio, "Compressive failure and size effect in plain concrete cylindrical specimens," Constr. Build. Mater., vol. 137, pp. 185-194, 2017, http://dx.doi.org/10.1016/j.conbuildmat.2017.01.057.

[29] A. M. Neville, Properties of Concrete, 5th ed. Harlow: Pearson, 2011.

[30] C. Ozyildirim and N. J. Carino, "Concrete strength testing," in Significance of Tests and Properties of Concrete and ConcreteMaking Materials, J. F. Lamond and J. H. Pielert, Eds., West Conshohocken: ASTM Int., 2006, ch. 13, pp. 125-140, http://dx.doi.org/10.1520/STP37731S.

[31] J. R. Del Viso, J. R. Carmona, and G. Ruiz, "Shape and size effects on the compressive strength of high-strength concrete," Cement Concr. Res., vol. 38, no. 3, pp. 386-395, 2008, http://dx.doi.org/10.1016/j.cemconres.2007.09.020.

[32] Ş. Yazıcı and G. İnan Sezer, "The effect of cylindrical specimen size on the compressive strength of concrete," Build. Environ., vol. 42, no. 6, pp. 2417-2420, 2007, http://dx.doi.org/10.1016/j.buildenv.2006.06.014.

[33] A. Carpinteri, "Scaling laws and renormalization-groups for strength and toughness of disordered materials," Int. J. Solids Struct., vol. 31, no. 3, pp. 291-302, 1994, http://dx.doi.org/10.1016/0020-7683(94)90107-4.

[34] Z. P. Bažant and J.-L. Le, Probabilist Mechanics of Quasibrittle Structures: Strength, Lifetime and Size Effect. Cambridge: Camb. Univ. Press, 2017. http://dx.doi.org/10.1017/9781316585146.

[35] Z. P. Bažant, "Probability distribution of energetic-statistical size effect in quasibrittle fracture," Probab. Eng. Mech., vol. 19, no. 4, pp. 307-319, 2004, http://dx.doi.org/10.1016/j.probengmech.2003.09.003.

[36] J. Vorel, M. Gattu, and Z. P. Bažant, "Size effect in flexure of prestressed concrete beams failing by compression softening," $J$. Struct. Eng., vol. 140, no. 10, pp. 1-8, 2014, http://dx.doi.org/10.1061/(ASCE)ST.1943-541X.0000983.

[37] Z. P. Bažant, Scaling of Structural Strength, 2nd ed. Burlington: Elsevier, 2005.

[38] A. Carpinteri, P. Cornetti, and N. Pugno, "Edge debonding in FRP strengthened beams: stress versus energy failure criteria," Eng. Struct., vol. 31, no. 10, pp. 2436-2447, Oct 2009, http://dx.doi.org/10.1016/j.engstruct.2009.05.015.

[39] M. Maalej and K. S. Leong, "Effect of beam size and FRP thickness on interfacial shear stress concentration and failure mode of FRP-strengthened beams," Compos. Sci. Technol., vol. 65, no. 7-8, pp. 1148-1158, Jun 2005, http://dx.doi.org/10.1016/j.compscitech.2004.11.010.

[40] J. F. Chen and J. G. Teng, "Anchorage strength Models for FRP and steel plates," J. Struct. Eng., vol. 127, no. 7, pp. 784-791, 2001, http://dx.doi.org/10.1061/(ASCE)0733-9445(2001)127:7(784). 
[41] X. Z. Lu, J. G. Teng, L. P. Ye, and J. J. Jiang, "Bond-slip models for FRP sheets/plates bonded to concrete," Eng. Struct., vol. 27, no. 6, pp. 920-937, 2005, http://dx.doi.org/10.1016/j.engstruct.2005.01.014.

[42] X. Z. Lu, L. P. Ye, J. G. Teng, and J. J. Jiang, "Meso-scale finite element model for FRP sheets/plates bonded to concrete," Eng. Struct., vol. 27, no. 4, pp. 564-575, Mar 2005, http://dx.doi.org/10.1016/j.engstruct.2004.11.015.

[43] S. A. Hadigheh, R. J. Gravina, and S. Setunge, "Identification of the interfacial fracture mechanism in the FRP laminated substrates using a modified single lap shear test set-up," Eng. Fract. Mech., vol. 134, pp. 317-329, Jan 2015, http://dx.doi.org/10.1016/j.engfracmech.2014.12.001.

[44] A. Hosseini and D. Mostofinejad, "Effective bond length of FRP-to-concrete adhesively-bonded joints: Experimental evaluation of existing models," Int. J. Adhes. Adhes., vol. 48, pp. 150-158, 2014, http://dx.doi.org/10.1016/j.ijadhadh.2013.09.022.

[45] H. Yuan, J. G. Teng, R. Seracino, Z. S. Wu, and J. Yao, "Full-range behavior of FRP-to-concrete bonded joints," Eng. Struct., vol. 26, no. 5, pp. 553-565, Apr 2004, http://dx.doi.org/10.1016/j.engstruct.2003.11.006.

Author contributions: LFB: conceptualization, metallic apparatus design, master's scholarship acquisition, experiment design, experimental work, data analysis, data interpretation, conclusions, writing, writing-review and editing. ACDS: conceptualization, supervision, planning of the project, methodology, funding acquisition, metallic apparatus design, experiment design, data analysis, data interpretation, conclusions, writing-review. All authors read and approved the final submitted version of this manuscript.

Editors: Ricardo Carrazedo, José Luiz Antunes de Oliveira e Sousa, Guilherme Aris Parsekian. 